\title{
Scrotal Melanoma
}

National Cancer Institute

\section{Source}

National Cancer Institute. Scrotal Melanoma. NCI Thesaurus. Code C7361.

A melanoma arising from the scrotum. 